\title{
DISCURSOS JUDICIAIS SOBRE FAVELAS \\ Impacto em políticas públicas e nos agentes sociais
}

\author{
Rafaela Selem Moreira
}

Universidade Federal Fluminense (UFF), Niterói - RJ, Brasil. E-mail: selemmoreira@gmail.com.

\section{Roberto Fragale}

Universidade Federal Fluminense (UFF), Niterói - RJ, Brasil. E-mail: roberto.fragale@gmail.com.

DOI: $10.17666 / 339608 / 2018$

\section{Introdução}

A Constituição brasileira de 1988, considerada símbolo da redemocratização brasileira, foi responsável pela ampliação formal do rol de direitos civis, políticos, econômicos, sociais, culturais e de terceira geração. Mesmo assim, é notória a incapacidade da administração pública de "dar conta" da demanda social por direitos que surgiu desde então. Estudiosos desse cenário (Junqueira, 1996; Santos, 2008) afirmam que isso gerou um deslocamento de legitimidade no pleito de direitos: dos poderes Executivo e Legislativo em direção ao poder Judiciário. Em outras palavras, o Judiciário tenderia a ser cada vez mais solicitado para dar materialidade a princípios e garantias constitucionais. "Esse movimento leva[ria] a que se cri[assem] expectativas

Artigo recebido em 10/03/2016

Aprovado em 24/05/2017 positivas elevadas a respeito do sistema judiciário, esperando-se que resolva os problemas que o sistema político não consegue resolver" (Santos, 2008, p. 21). De fato, desde a década de 1980 , verificou-se o crescimento de demandas e julgados versando sobre as favelas, até mesmo com seus moradores eventualmente figurando como autores (Moreira e Cittadino, 2013). Mais especificamente nos últimos dez anos, o Judiciário passou a ser cada vez mais requisitado para discutir problemáticas relacionadas com as favelas e com a vida de seus moradores, isto é, grupos sociais desprivilegiados economicamente (Moreira, 2011). Se, por um lado, a demanda por direitos cresceu ao longo do tempo, é sugestivo inferir que a atuação do poder Judiciário em resposta constitui variável que atua ativamente na construção desse cenário. Uma decisão judicial pode retroalimentar (ou não) a busca ativa de direitos no sistema formal de justiça. Nesse sentido, chegamos à questão central de nossa análise: como 
o discurso do Tribunal de Justiça do Rio de Janeiro (TJRJ) vem sendo construído nesse cenário? Quanto da percepção dos magistrados pode ser observado a partir do conteúdo e do discurso a respeito das decisóes judiciais e como estas se relacionam com as políticas públicas? Teceremos, inicialmente, algumas consideraçóes quanto ao método de análise de nossa amostra: o discurso contido na jurisprudência do TJRJ no período de 1980 a 2009 para casos envolvendo favelas e seus moradores.

\section{Corpus: consideraçóes sobre a amostra}

Nosso recorte amostral teve como base a amostra da pesquisa de Moreira (2011): seleção de julgados do TJRJ filtrados com base na palavra chave "favela", ${ }^{1}$ em janeiro de 2011. Quanto à origem, o filtro foi o âmbito da justiça civil. Muito mais que na justiça penal, aqui é possível falar em procura real à justiça (Santos, 1989). ${ }^{2}$ O pré-teste para o recorte temporal estabeleceu o ano base de 1980, considerando a democratização do Brasil e a promulgaçáo da Constituição nessa década. ${ }^{3}$ Ao final, foi verificado que não havia qualquer julgado no TJRJ com a palavra "favela" antes dos anos de 1980. A análise de Moreira abrangeu três décadas, de 1980 a 2009, com um total de 150 decisōes judiciais. ${ }^{4} \mathrm{O}$ objetivo deste trabalho é testar categorias analíticas e colocá-las em debate na comunidade acadêmica com vistas a melhor aferir como o discurso dos tribunais vem sendo construído na dialética com atores sociais e políticos. Nossa amostra de três décadas reuniu um total de 150 decisões judiciais - sendo quatro entre 1980 e 1989, 51 entre 1990 e 1999 e 95 entre 2000 e 2009 - com um total de 42.649 palavras que são aqui analisadas detalhadamente quanto ao conteúdo e construção discursiva.

\section{A análise: consideraçóes sobre o método}

O uso da linguística aplicada a discursos produzidos em contextos jurídicos tem uma longa tradiçāo nos países de língua inglesa. Segundo Pádua (2009, p. 5), os múltiplos usos das ferramentas linguísticas de análise envolvem desde problemas sintá- ticos, semânticos e pragmáticos na interpretação de textos de normas jurídicas até análises linguísticas de discursos orais e escritos. Infelizmente, contudo, no Brasil os estudos dedicados a essa interface entre direito e linguística são ainda incipientes. Mais do que traduzir lutas ou sistemas de dominação, os discursos são instrumentos de luta, são manifestação de poder em si (Foucault, 1998). O discurso verdadeiro, segundo Foucault (1998, p. 5), é o que a justiça "diz" e "atribui" a cada um, pois anunciam o futuro - o discurso judicial. Assumimos como referência teórica para aspectos metodológicos as análises de Fairclough (2001), que mostram a impossibilidade de um procedimento fixo para análise do discurso. Fatores como a natureza específica do projeto ou as visōes do discurso podem afetar a forma como a análise será feita. Os dados, a análise e os resultados são os três principais itens considerados no processo. Como a prática discursiva é uma faceta da prática social, aquela diz muito sobre esta e sobre as instituiçóes. Desse modo, é fundamental, em primeiro lugar, a definiçấo do corpus $^{5}$ e, na sequência, a escolha das categorias analíticas aplicadas a este corpus. No geral, a análise contemplou o número de palavras por ementa, as palavras mais repetidas e o magistrado, ou seja, o desembargador que proferia a decisão. Quanto aos aspectos intra e inter-relacionados ao Judiciário, tanto para dentro como para fora da instituiçáo, foram examinados os atores sociais e políticos citados; o tipo de relação estabelecida; ${ }^{6}$ e a construçáo do ego, isto é, características do ethos e da polidez ${ }^{7}$ na fala e o uso da adjetivação. Analisamos ainda a presença de fundamentos do direito de forma expressa e, por fim, a lógica e a coerência na construção da decisão. Vale registrar que toda a análise contida neste trabalho foi feita com base nas ementas dos julgados, o que equivale ao resumo do conteúdo das decisooes. ${ }^{8}$ Sobre a perspectiva do discurso como prática social é preciso ainda termos clareza quanto ao contexto de sua produção. Trata-se de produção discursiva elaborada nas dependências de um prédio público (TJRJ), seja em um gabinete (julgamento individual), seja em uma câmara de audiências (julgamento coletivo), geralmente sem qualquer contato com as partes envolvidas, tampouco com o cenário do litígio, no caso, a favela. 


\section{A favela requer normatividade democrática estatal: breve trajetória}

Muito antes de chegar ao Judiciário nos anos de 1980, a favela já era um fenômeno social, contando com um século de existência na cidade do Rio de Janeiro. Uma história complexa, fluida e envolta em ambiguidades e choques de percepçáo, especialmente nas políticas empreendidas nas diferentes gestóes do poder Executivo. As políticas públicas oscilavam entre acolhimento e remoçáo, colocando em evidência a capacidade de resistência de seus moradores. Na década seguinte, a favela era fato social consolidado: os barracos de madeira deram lugar a construçóes em alvenaria e as remoçóes, a programas de integração, como o programa municipal favela-bairro. Nos discursos oficiais desaparece, portanto, a visão médico-sanitarista dos anos de 1920, segundo a qual as favelas eram uma doença social a ser eliminada. É nesse contexto que o debate alcança o poder Judiciário, ainda que tímidamente - apenas 3\% de nossa amostra - e oriundo de açóes propostas por moradores da cidade. Os autores dessas demandas eram proprietários de imóveis localizados na cidade formalmente constituída que viram seu patrimônio desvalorizado ou ameaçado em virtude da ocupaçáo irregular de terrenos. Revoltados contra o Estado, passaram a reivindicar judicialmente não só indenizações pelo prejuízo sofrido em seu patrimônio, mas também a atuação da administração pública para a remoção das favelas. Assim, aparentemente, as primeiras demandas judiciais na década de 1980 surgiram na contramão da história, uma vez que no âmbito do Executivo já não se falava mais em remoção ou eliminação de favelas. E, naquele momento, a postura dos desembargadores do TJRJ foi de evitar a tomada de decisão, preferindo não interferir nessas questóes (Moreira, 2011).

Uma década depois, a favela ganhou fama, não como resultado dos cem anos de história de lutas por sobrevivência, mas como consequência da degeneração de valores e da violência gerada pelo crime - o tráfico de drogas. Tanto no cenário nacional - por intermédio da televisão e da grande imprensa - quanto no cenário internacional - nas telas de cinema -, havia certo fetichismo
(Bauman, 2009) na divulgação da violência e da atmosfera de ilegalidade que cercavam as favelas cariocas, decorrência da escassez de dados e de uma mídia pouco esclarecedora acerca da realidade das favelas e de suas dimensóes na cidade. Vale lembrar que a primeira favela do Rio de Janeiro já contava com cinquenta anos de existência quando se decidiu pela realização de um recenseamento específico (Valladares, 2005, p. 62). ${ }^{9}$ A demora e a insuficiência na geração de dados aliadas às especulaçóes alarmistas da imprensa criaram perspectivas fantasiosas e irreais desses espaços urbanos. Exemplo disso é a visão do Rio de Janeiro como uma "cidade partida" (Ventura, 1995).

Nos anos de 1990, portanto, o cenário das comunidades faveladas mudou para pior no que tange à segurança pública e à qualidade de vida de seus moradores. Diante da falta de recursos e da violência que ganhou força com os traficantes cada vez mais armados, as organizações comunitárias tornaram-se frágeis e fragmentadas, e o poder público (municipal e estadual) passou a enfrentar dificuldade para prestar serviços e executar obras de urbanização e saneamento. Além disso, reduziram-se muito os espaços públicos comunitários legítimos, seguros e disponíveis para a resolução dos conflitos, que antes eram discutidos diretamente na sede de organizaçóes comunitárias (Santos, 1988; Moreira, 2006). As lideranças tornaram-se cada vez mais escassas, sendo expulsas, assassinadas ou corrompidas na guerra contra (e pelo) tráfico de drogas e na disputa das urnas. Foi justamente nesta época, quando os meios locais de resolução de conflitos estavam fragilizados ou eram inexistentes, que novas demandas judiciais por parte dos próprios moradores das comunidades começaram a aparecer no sistema formal de justiça. Suas reivindicações diziam respeito a acidentes com projetos de urbanização e "balas perdidas"10 na guerra entre policiais e traficantes. A partir daí, o número de demandas nesse sentido aumentou consideravelmente, incitando um maior posicionamento do TJRJ. Chama a atenção o fato de os magistrados passarem a discutir questóes sociais e políticas relativas às favelas sobre as quais se abstiveram nos anos anteriores. $\mathrm{O}$ TJRJ começa, então, a tomar decisóes em casos polêmicos, que requerem um posicionamento político 
quanto à atuação da administração pública, e os desembargadores passam a fazer análises do contexto social em demandas oriundas das favelas. ${ }^{11}$ Pudemos identificar, nesse período, decisóes criativas de juízes que extrapolaram o dispositivo da lei em busca de uma decisão social ou política mais eficaz. Em apenas 6\% dos julgados, nos anos de 1990, o tribunal entendeu que a administração pública tinha sido omissa, não conseguindo evitar ocupaçóes irregulares. Nesses casos, optavam pela remoção das favelas, mas o conflito entre a realidade social consolidada da favela e esse tipo de decisão inviabilizava sua execução, gerando ineficácia e perda de confiança nas instituiçóes judiciais. Contudo, a partir dos anos 2000, o TJRJ demonstra uma mudança na compreensão desse cenário e, uma transformação na postura de seus magistrados. Há, por exemplo, relatos de juízes que adentraram as favelas para inspecionar localmente conflitos e balizar suas decisóes em demandas propostas por moradores das comunidades (Moreira, 2011). Com efeito, a reincidência das demandas iniciadas nos anos de 1990 foi projetada na década seguinte, o que, de alguma forma, provocou uma transformação na mentalidade dos juízes e dos desembargadores, que passaram a tomar decisóes diferenciadas. Tal reincidência aproximou "favela" dos gabinetes do TJRJ, gerando decisões mais afinadas com a prática social.

Por outro lado, observa-se nas favelas a expansão de grupos de policiais corruptos - conhecidos como "milícias" - que entram em disputa territorial com traficantes pela dominação do território das favelas. São indivíduos sem qualquer vínculo com a comunidade, ligados a políticos e instituiçóes do Estado, o que aguça o medo da populaçáo local. Com o programa de pacificação iniciado em 2008, o Estado entrou oficialmente na disputa por territórios dominados pelo tráfico e por milicianos. $\mathrm{O}$ objetivo era restabelecer a sociabilidade democrática nesses "feudos"; para tanto, unindo esforços do governo federal e estadual, houve uma canalização de recursos para obras de infraestrutura, moradia e serviços nas favelas. O Programa de Aceleração do Crescimento (PAC) - com projetos como o Minha Casa, Minha Vida -, a UPP Social da prefeitura em parceria com o Programa das Naçóes Unidas para os Assentamentos Urbanos (ONU Habitat) e os investimentos de empresas e organizaçóes não governamentais passaram a disputar esses espaços, onde foi ficando mais comum o trânsito de pesquisadores. Turismo, comércio e cidadania são termos que aparecem com cada vez mais frequência quando se faz referência às favelas cariocas. Se, na eleição municipal anterior à pacificação, os moradores queriam acesso a postos de saúde com médicos e infraestrutura, na eleição seguinte, com as Unidades de Pronto Atendimento (UPAs) funcionando, nota-se um refinamento das reivindicaçóes a população começa, por exemplo, a questionar a demora de três meses para o agendamento de exames. $\mathrm{O}$ parâmetro da reivindicação ganha mais um argumento: o direito adquirido na qualidade de pagador de impostos. A efervescência das interaçóes de mundos viabilizadas com o "respiradouro" de sociabilidade democrática possibilitou um avanço, mas é preciso que seus reflexos no sistema de justiça sejam medidos, o que discutiremos a seguir.

\section{Interesses em jogo: foco nas demandas}

Conhecer os demandantes é fundamental para entender o contexto social que alicerça as reivindicaçôes que chegam ao Judiciário. Analisaremos nesta seção os interesses em jogo com base no perfil dos demandantes e dos réus.

Entre os demandantes, encontramos, em primeiro lugar, os moradores de favelas, ${ }^{12}$ com $51 \%$ da autoria das açôes, seguidos pelos não moradores de favelas (38\%) e por pessoas jurídicas, Estado e Ministério Público (11\%). Vale registrar que as açóes propostas pelo Ministério Público e pessoas jurídicas com sede fora da favela são, em geral, de interesse coletivo e/ou difuso, ou seja, ações coletivas e ações civis públicas. Esse tipo de ação só foi encontrado na década de 1980, mas não houve ali incidência de açóes propostas por moradores de favelas. Com o passar do tempo, isso começa a mudar. Os anos de 1990 apresentam um número crescente de demandas oriundas de moradores de favelas de 1980 a 1999, 34\% das demandas eram de moradores de favelas, e na primeira década dos anos 2000 este número se torna ainda mais significativo: $58 \%$ do total do recorte amostral. Este cenário, nos 


\section{Gráfico 1 \\ Perfil dos Demandantes no TJRJ em Açóes Propostas entre 1980 e 2009}

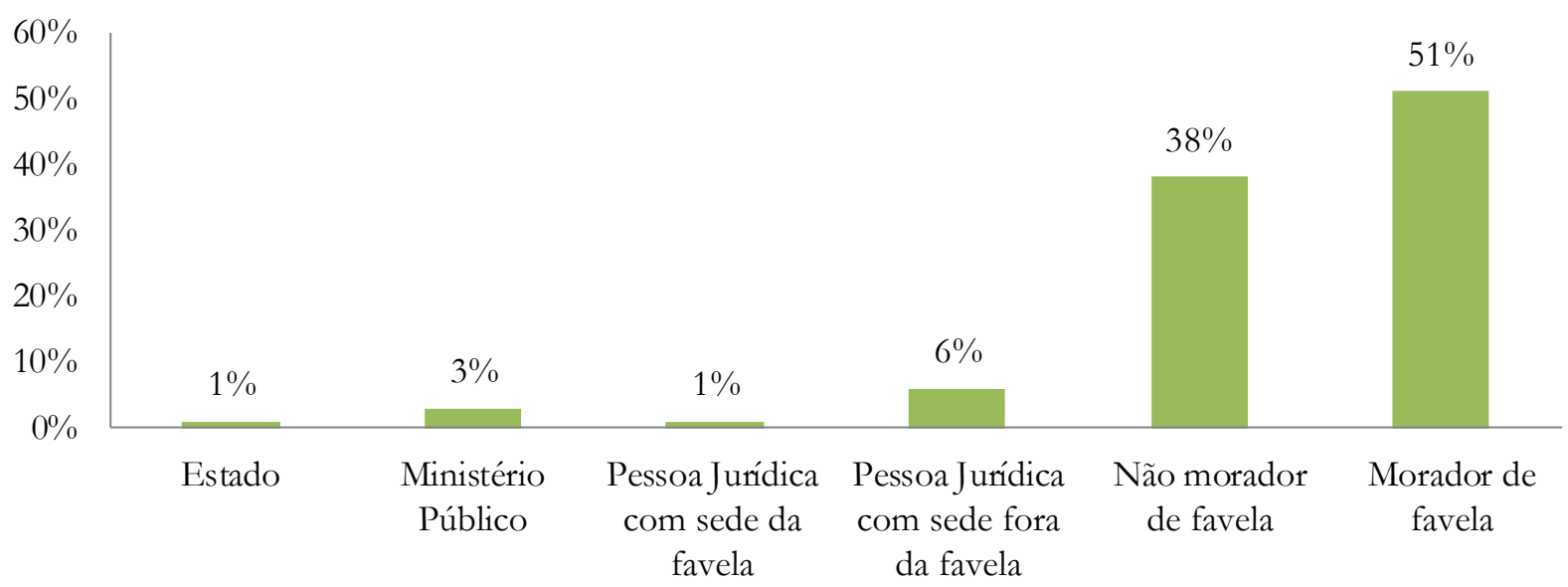

Fonte: Gráfico feito com base em levantamento de dados de autoria dos autores. Levantamento de dados a partir da jurisprudência do Tribunal de Justiça do Rio de Janeiro (TJRJ) entre os anos de 1980 e 2009. Palavra de busca: favela. Local de busca: website do tribunal. Total da amostra correspondente à: 4 (quatro) ementas de julgados entre $1980 \mathrm{e}$ 1989; 51 ementas de julgados entre 1990 e 1999; 95 ementas de julgados entre 2000 e 2009. Um total de 150 julgados, correspondente à 42.649 palavras em análise.

últimos dez anos, vem apresentando novos contornos com o notável aumento de demandas de moradores de favelas na qualidade de consumidores, o que sugere uma nova forma de cidadania (Holston, 2013). Entre as reformas no Judiciário efetuadas na década de 1990, observa-se o sucesso dos Juizados Especiais Cíveis.

A primeira ação proposta data de 1993. Trata-se de demanda apresentada por um morador de favela sobre uma situação que envolvia o valor de um imóvel construído por um casal em processo de divórcio. Como a grande maioria dos imóveis nas favelas é irregular e, portanto, judicialmente não possui valor comercial, o juiz da primeira instância - em respeito ao direito positivo e à "ordem pública"- não considerou a partilha do imóvel, uma vez que, de seu ponto de vista, se tratava de um imóvel juridicamente inexistente. Essa demanda chegou ao Tribunal de Justiça, que se posicionou à altura da provocação, determinando que, sim, o imóvel possuía valor eco- nômico e que o juiz da primeira instância procedesse à partilha do bem. ${ }^{13}$ Apesar da inovação que o caso representa na relação entre o direito e a prática social, é relevante ponderar que entendimentos diversos foram manifestados por outros desembargadores do TJRJ em casos semelhantes. ${ }^{14}$

Quanto ao perfil do demandado, o réu é o Estado na grande maioria dos casos. No entanto, o crescimento notável de demandas de consumo coloca cada vez mais pessoas jurídicas no banco dos réus, sendo essa nova cidadania responsável pelo significativo percentual observado no Gráfico 2 .

Como podemos observar, em todos os períodos, e no quadro geral, o principal réu, quando o assunto é favela, é o Estado. No entanto, se de 1980 a $1999,86 \%$ das demandas eram reclamaçôes contra o Estado, na virada para os anos 2000, aumentou de $7 \%$ para $18 \%$ o percentual de demandas contra pessoas jurídicas, distribuindo as reclamaçóes entre as atuaçóes do público (67\%) e privado (33\%). Por 


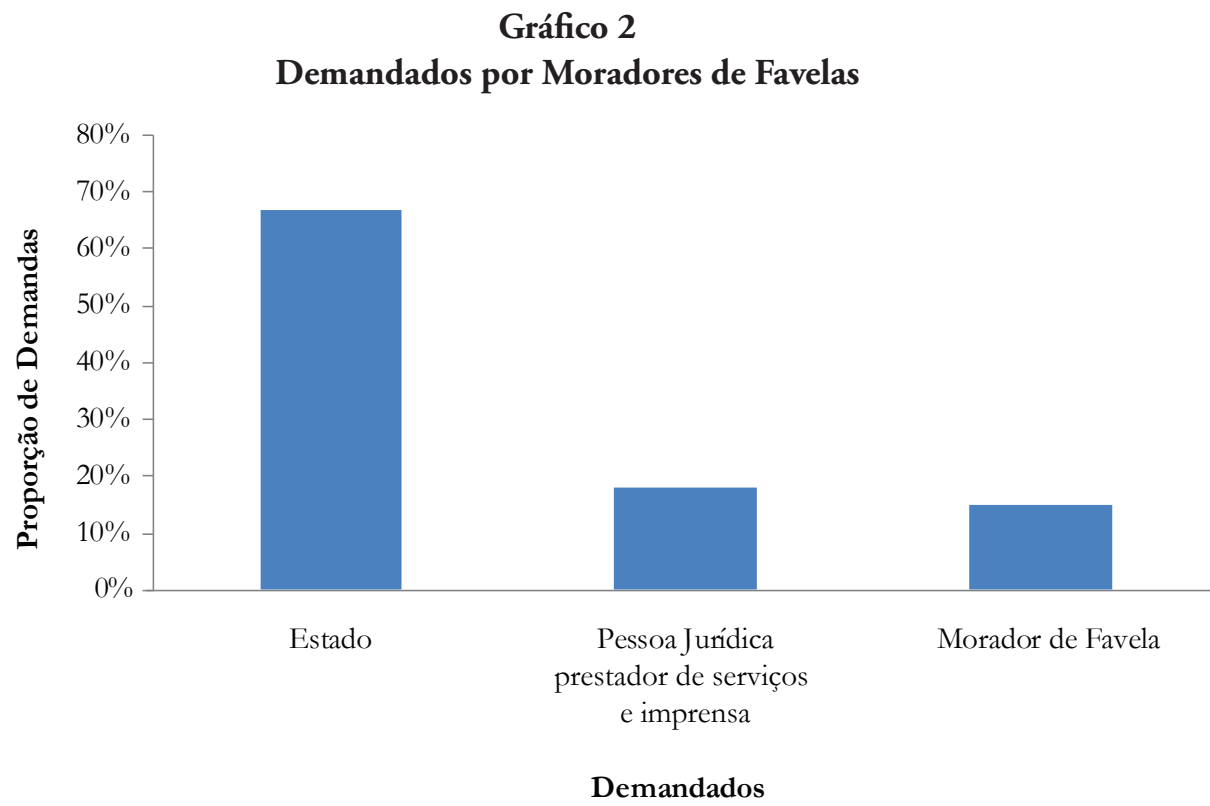

Fonte: Gráfico feito com base em levantamento de dados de autoria dos autores. Levantamento de dados a partir da jurisprudência do Tribunal de Justiça do Rio de Janeiro (TJRJ) entre os anos de 1980 e 2009. Palavra de busca: favela. Local de busca: website do tribunal. Total da amostra correspondente à: 4 (quatro) ementas de julgados entre $1980 \mathrm{e}$ 1989; 51 ementas de julgados entre 1990 e 1999; 95 ementas de julgados entre 2000 e 2009. Um total de 150 julgados, correspondente à 42.649 palavras em análise.

sua vez, o perfil das demandas está diretamente ligado à atuação do Estado e das empresas nessas áreas. A década de 1990 é marcada por obras de urbanização e infraestrutura, como o projeto Favela-Bairro, iniciado na década anterior, e ainda pela atuação policial no combate ao crime organizado. O período dos anos 2000 é marcado pela expansão da base da pirâmide brasileira de direitos - modelo de cidadania democrática de Marshall (Carvalho, 2002) -, nos dois governos de Lula, com a priorização da distribuição de direitos sociais, criando uma legiāo de consumidores, por vezes politicamente desarticulados pelas seduçóes do mercado (Holston, 2013). À luz desse paralelo com a prática política e social em nível macro e, ao mesmo tempo, dos cenários sociais e políticos no nível da vida mais cotidiana da cidade, podemos nos voltar mais detidamente para o perfil das demandas e avaliar como isto se reflete nas instituiçóes de justiça.

Ao longo de três décadas, 35,5\% (53) das demandas versam sobre propriedade e patrimônio, e 33,5\% (50), sobre vida e integridade física. Esses números, à luz do proponente, revelam que as pri- meiras são propostas por pessoas que não moram emfavelas, ao passo queas segundas, porquem moraem favelas. O perfil da demanda tem relação direta com o perfil do demandante e nos ajuda a acessar um pouco do seu mundo diário: valores e questóes de justiça, qualidade de vida e necessidades.

Quando o assunto é vida e integridade física, "bala perdida", assunto ligado majoritariamente à ação policial do Estado, é a principal reivindicação dos moradores de favelas, assim como demandas de usucapiấo e serviços vinculados a obras de urbanização de favelas que deixam mortos ou feridos. Os moradores de áreas formais, em contrapartida solicitam indenizaçóes por desvalorização de imóveis, afetação e danos gerados pelas favelas ao meio ambiente e demais tipos de violência urbana. ${ }^{15}$ Contudo, nesta última década analisada, o morador de favela aparece na qualidade de consumidor perante o TJRJ. Os demais direitos fundamentais e civis são açóes que demandam gratuidade de justiça, honra e reputação, entre outras como disputa entre vizinhos e divórcios, como vimos nos gráficos acima. 
Gráfico 3

Bem Tutelado entre 1980 e 1999

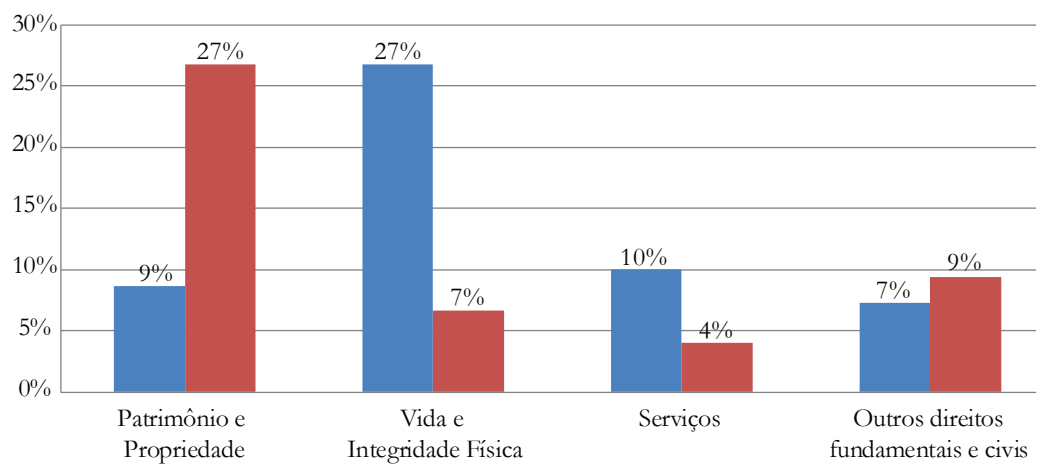

- Morador de Favela $\square$ Não Morador de Favela

Fonte: Gráfico feito com base em levantamento de dados de autoria dos autores. Levantamento de dados a partir da jurisprudência do Tribunal de Justiça do Rio de Janeiro (TJRJ) entre os anos de 1980 e 2009. Palavra de busca: favela. Local de busca: website do tribunal. Total da amostra correspondente à: 4 (quatro) ementas de julgados entre $1980 \mathrm{e}$ 1989; 51 ementas de julgados entre 1990 e 1999; 95 ementas de julgados entre 2000 e 2009. Um total de 150 julgados, correspondente à 42.649 palavras em análise.

\section{Gráfico 4}

\section{Perfil das Demandas no TJRJ, Considerando o Perfil do Demandante e o Tipo de Demanda}

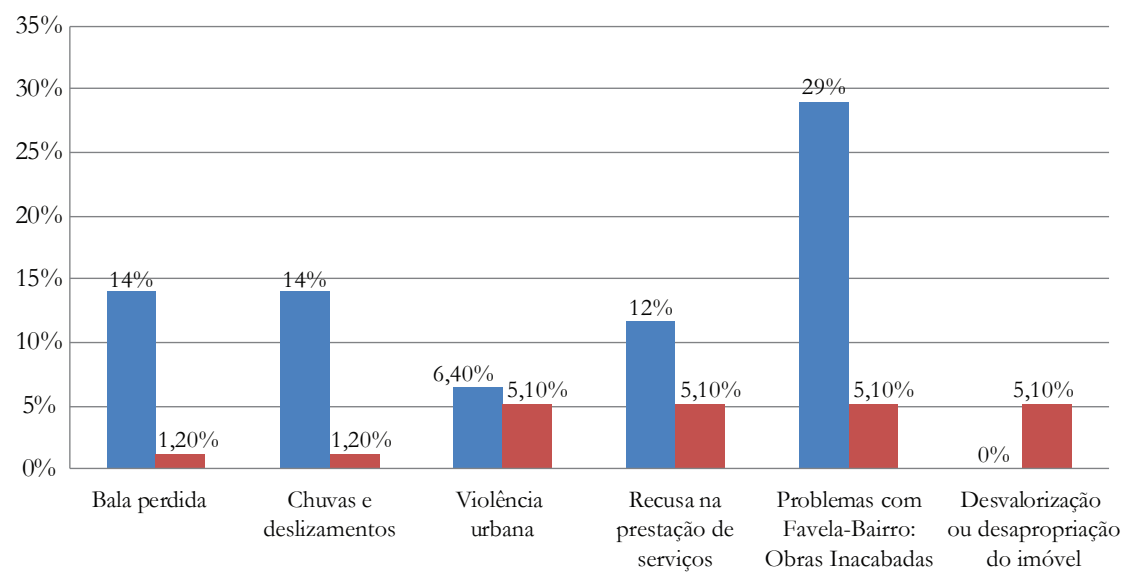

- Morador de Favela $\square$ Não Morador de Favela

Fonte: Gráfico feito com base em levantamento de dados de autoria dos autores. Levantamento de dados a partir da jurisprudência do Tribunal de Justiça do Rio de Janeiro (TJRJ) entre os anos de 1980 e 2009. Palavra de busca: favela. Local de busca: website do tribunal. Total da amostra correspondente à: 4 (quatro) ementas de julgados entre $1980 \mathrm{e}$ 1989; 51 ementas de julgados entre 1990 e 1999; 95 ementas de julgados entre 2000 e 2009. Um total de 150 julgados, correspondente à 42.649 palavras em análise. 


\section{Gráfico 5}

Variação no Número de Palavras por Ementa de Julgados

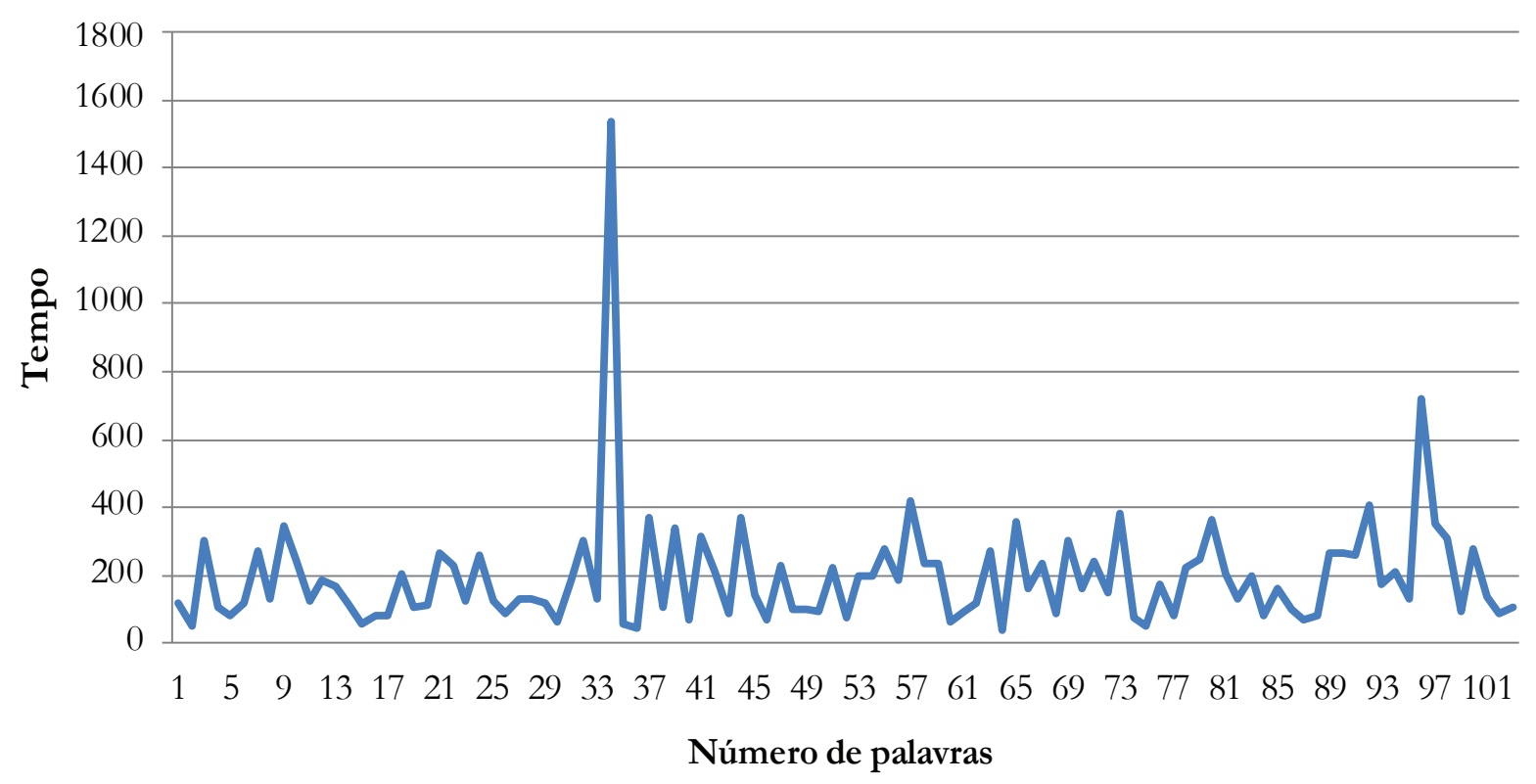

Fonte: Gráfico feito com base em levantamento de dados de autoria dos autores. Levantamento de dados a partir da jurisprudência do Tribunal de Justiça do Rio de Janeiro (TJRJ) entre os anos de 1980 e 2009. Palavra de busca: favela. Local de busca: website do tribunal. Total da amostra correspondente à: 4 (quatro) ementas de julgados entre $1980 \mathrm{e}$ 1989; 51 ementas de julgados entre 1990 e 1999; 95 ementas de julgados entre 2000 e 2009. Um total de 150 julgados, correspondente à 42.649 palavras em análise.

\section{Análise do discurso: um olhar sobre a construçáo discursiva de decisóes}

Como vimos, nossa amostra abrange o período entre 1980 e 2009, quando $51 \%$ da autoria de açóes foram de moradores de favelas - se somarmos a este número $1 \%$ de pessoas jurídicas com sede em favelas, tem-se um total de $52 \%$ de demandas -, um cenário conformado na última década desta amostra, onde estão concentrados mais de dois terços da jurisprudência analisada. Contra o Estado, os dados indicam $67 \%$ das demandas e mais de $80 \%$ destes julgados são recursos de apelação, ou seja, decisóes tomadas em órgãos colegiados. Em quase $80 \%$ dos casos o pedido é de indenização, mas o pano de fundo varia, sendo $35,5 \%$ por questóes envolvendo patrimônio e propriedade e 33,5\% em função da perda da vida ou integridade física - e ainda $10 \%$ pela falha na prestação de serviço de consumo. As ementas analisadas correspondem ao relato de vinte órgãos colegiados $^{16}$ do TJRJ. Mais especificamente, estamos tratando da fala de 71 desembargadores, ${ }^{17}$ entre eles três ex-presidentes do TJRJ e um atual ministro do Supremo Tribunal Federal (STF). Seguimos, portanto, à análise das 42.649 palavras que consubstanciam este conjunto de ementas.

O número de palavras das ementas do TJRJ não é padronizado, variando entre 38 e 1.539. Dentre os termos mais repetidos, destacam-se: indenização (66), risco (44), Constituição Federal ${ }^{18}$ (42), omissão (40), morte (39), desapropriação (29), prestadora (17), bandidos (17) e desvalorização (10). Depois de indenização, a palavra mais repetida em todo o corpus de análise foi risco para referir-se tanto a situaçóes de 


\section{Gráfico 6}

“Tipos de Relaçáo” Discursiva Estabelecida com Atores Sociais e Políticos

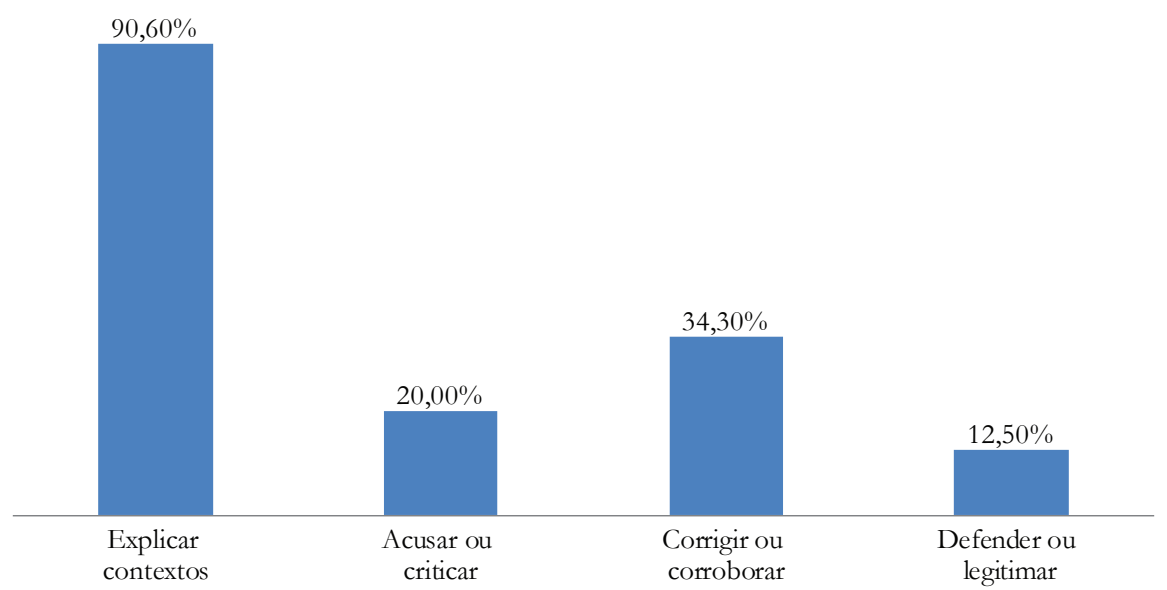

Fonte: Gráfico feito com base em levantamento de dados de autoria dos autores. Levantamento de dados a partir da jurisprudência do Tribunal de Justiça do Rio de Janeiro (TJRJ) entre os anos de 1980 e 2009. Palavra de busca: favela. Local de busca: website do tribunal. Total da amostra correspondente à: 4 (quatro) ementas de julgados entre $1980 \mathrm{e}$ 1989; 51 ementas de julgados entre 1990 e 1999; 95 ementas de julgados entre 2000 e 2009. Um total de 150 julgados, correspondente à 42.649 palavras em análise.

\section{Gráfico 7}

Ethos e Polidez nas Relaçóes Discursivas Estabelecidas com Atores Sociais e Políticos

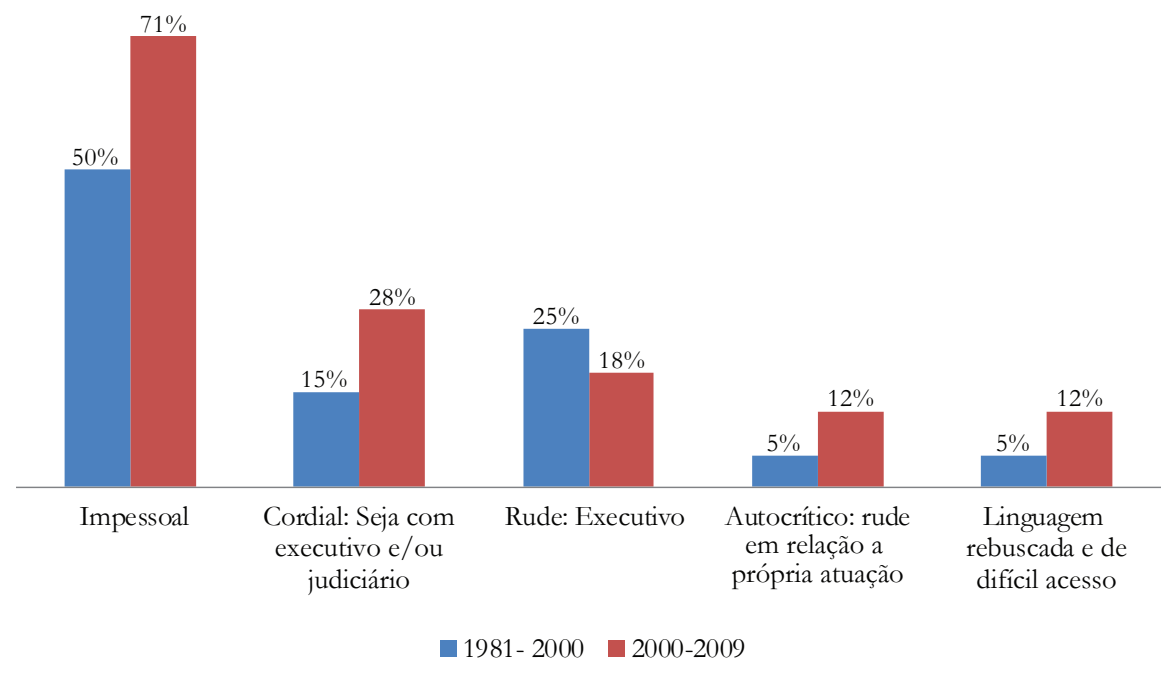

Fonte: Gráfico feito com base em levantamento de dados de autoria dos autores. Levantamento de dados a partir da jurisprudência do Tribunal de Justiça do Rio de Janeiro (TJRJ) entre os anos de 1980 e 2009. Palavra de busca: favela. Local de busca: website do tribunal. Total da amostra correspondente à: 4 (quatro) ementas de julgados entre $1980 \mathrm{e}$ 1989; 51 ementas de julgados entre 1990 e 1999; 95 ementas de julgados entre 2000 e 2009. Um total de 150 julgados, correspondente à 42.649 palavras em análise. 
risco como à teoria do risco administrativo pela qual o poder Executivo responde por danos, independentemente de culpa, em todas as suas açóes e/ou omissóes. Na sequência, a terceira palavra mais repetida foi Constituição Federal, utilizada como referência para a fundamentação de decisóes. Destacamos ainda omissão, a quarta palavra mais repetida, sempre em referência à atuação do poder Executivo e por vezes qualificada como omissão abusiva.

Esta primeira análise sugere a falta de padronização nas decisóes do TJRJ e um possível atrito com o poder Executivo. Seguimos nessa exploração com categorias analíticas forjadas para aferir de forma mais qualificada o relacionamento do TJRJ não só com outras instâncias e órgãos de justiça, mas também com outras esferas de poder e da sociedade civil. Atores políticos e sociais são citados expressamente para: (1) reconstruir aspectos processuais - por exemplo, o autor, o réu, o voto vencido - e reconstruir fatos e contextos sociais para o julgamento; ${ }^{19}$ (2) embasar discursos militantes, políticos e críticos mais subjetivos em tom de desabafo ${ }^{20}$ - por exemplo, entes do poder Executivo; (3) discursos paternalistas em tom protetor $^{21}$ - por exemplo, jovens moradores de favelas; e (4) autocríticos ${ }^{22}$ - por exemplo, colegas de primeira instância e peritos.

Mais especificamente, quando o ator social é um indivíduo que reside na favela, a caracterização discursiva do TJRJ nos diz um pouco sobre as lentes sociais e políticas dos julgadores: a expressão "morador da favela” (63 referências expressas) é a mais repetida, o que nos aproxima da ideia de Holston (2013) de que a cidadania está associada à condição de moradia urbana. Aparecem ainda - e apresentamos na ordem de recorrência- os seguintes termos para qualificar o morador da favela: morador (31), cidadão (10), pobre (9), meliante (5), trabalhador (3), criminoso (2) e suspeito (1). Para melhor qualificar o relacionamento do TJRJ com atores sociais e políticos, analisamos o aspecto da constituição do ego dos desembargadores, tomando por base aspectos de polidez e ethos (Fairclough, 2001). As pistas discursivas indicaram, então, um ego mutante no período estudado aqui (ver Gráfico 7).

O conjunto de dados sugere constataçóes de ordem qualitativa. A diferenciação entre, de um lado, o Estado e, de outro, o poder Judiciário, como se o segundo não estive contido no primeiro, está muito presente no discurso do tribunal, sobretudo porque se critica a omissão, a má-fé e o não cumprimento das decisóes judiciais por parte do Executivo. Ao se identificar como um órgão diferenciado, a constituição desse ethos vem acompanhada de um quê de "justiceiro social" diante de demandas sobre as favelas no estado do Rio de Janeiro. O Judiciário passou, então, a fixar soluçôes que muitas vezes não poderiam ser executadas. Com o passar do tempo, o discurso dos desembargadores revela uma mudança de postura, cada vez mais impessoal, menos crítica e mais inclinada a decisóes que ponderam os limites da atuação do poder Executivo, e sem "pirotecnia". Com base em princípios que regem a responsabilidade civil da administração pública, os juízes passaram, por exemplo, diretamente ao arbitramento de uma compensação indenizatória sem inflamar o antagonismo com a atuação da administração pública. Não há mais necessidade de discursos políticos nem de citar o tempo todo a Constituição, como se a Carta, a realidade da favela e a atuação do poder Executivo entrassem, de alguma forma, no "senso comum" dos julgadores. O TJRJ passou a proferir decisóes cada vez mais condizentes e factíveis com a realidade da favela (Moreira, 2011) enquanto fato social absolutamente consolidado, o que é também evidenciado no discurso dos desembargadores em relação ao Executivo. Em outras palavras, esta análise sugere que a recorrente judicialização da política em demandas individuais vem aproximando as realidades do Judiciário e dos órgãos do Executivo: o sistema de justiça cada vez mais conhece os limites e as possibilidades do poder Executivo. Antes acusado de morosidade, apatia e incompetência, passa a ser visto com mais objetividade.

Existe um processo em movimento de mudança de ethos-de "justiceiro", dissociado do seu papel de Estado, para um Judiciário que integra o Estado, mas não se mistura com a conduta de um poder Executivo falho e ineficaz. Isso mostra como o Judiciário conhece cada vez mais os meandros que levam aos erros no funcionamento do Executivo. Os dados sugerem ainda que a postura acolhedora praticada pelo poder Judiciário para demandas que judicializam falhas na prestação de políticas públicas, combinada com o ego diferenciado em relação 


\section{Gráfico 8 \\ Elementos Considerados na Fundamentação da Decisão}

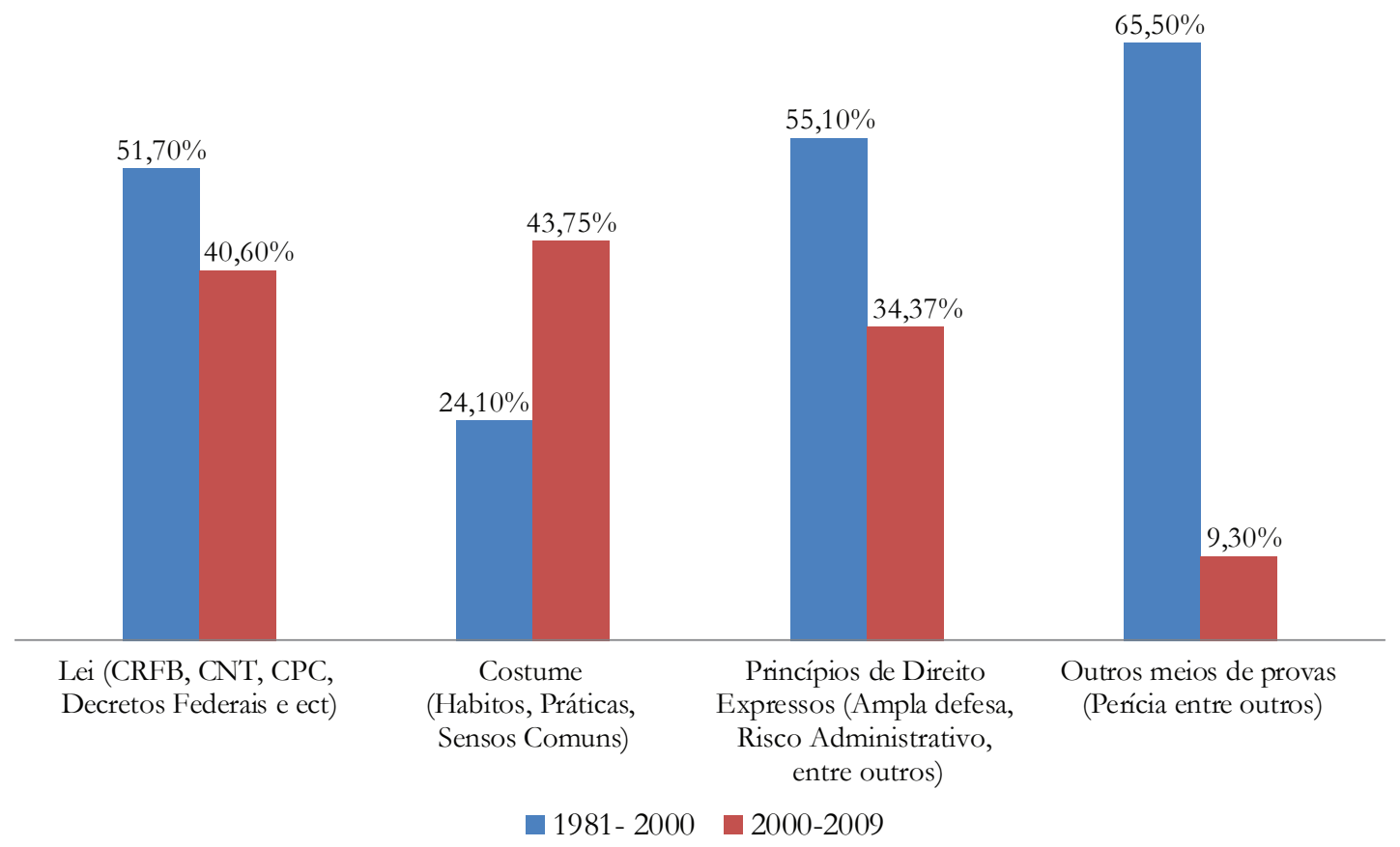

Fonte: Gráfico feito com base em levantamento de dados de autoria dos autores. Levantamento de dados a partir da jurisprudência do Tribunal de Justiça do Rio de Janeiro (TJRJ) entre os anos de 1980 e 2009. Palavra de busca: favela. Local de busca: website do tribunal. Total da amostra correspondente à: 4 (quatro) ementas de julgados entre $1980 \mathrm{e}$ 1989; 51 ementas de julgados entre 1990 e 1999; 95 ementas de julgados entre 2000 e 2009. Um total de 150 julgados, correspondente à 42.649 palavras em análise.

ao Executivo, tem sido um grande incentivo para novas reivindicaçóes com as mesmas características. Em uma checagem para fins de redimensionamento do corpus da amostra, refizemos a busca na jurisprudência do TJRJ a partir da palavra chave "favela” em março de 2016, encontrando um novo total de 469 decisões. Em outras palavras, entre 2010 e 2016 há 421 novas decisóes correspondentes a ações propostas entre 2000 e 2009 . Um número significativamente maior que a amostra original aqui trabalhada (150 decisóes).

Apesar de, em sua maioria, as demandas serem propostas por pessoas físicas diante do Estado, o discurso do TJRJ é orientado - público-alvo - à própria instituição pública - o Judiciário - ou ao Executivo enquanto instituição. Não foram identificados aspectos de participação do usuário (partes) no discurso ou na sua destinaçáo. $\mathrm{O}$ mais próximo a que se chega das partes é a interação com o patrono, mesmo assim em casos isolados.

Por fim, verificamos a presença de elementos de direito na ponderação das decisóes e, ainda, o que alicerça a decisão final dos magistrados: "fundamentos de direito expressos" e "intertextualidade na construção da decisão". Como categorias analisadas, consideramos "lei", "costumes", "princípios de direito" e "outros fundamentos" como os meios de prova por exemplo, perícia - e a doutrina. Em 100\% das ementas até 2000, havia algum tipo de fundamento de direito expresso, cenário que se transformou na última década, conforme o Gráfico 8.

A categoria com maior ocorrência, no período entre 1989 e 2000, foi "outros fundamentos" (65,5\%). Nesta, também contabilizamos um tipo 
diferenciado de prática em funçáo da sua reincidência. Percebemos que os desembargadores consideravam as narrativas contidas em sentenças de juízes de primeira instância uma base para formação de seu entendimento acerca da questão em julgamento. Essas narrativas eram, em geral, apropriadas pelo desembargador-relator, sem compromisso com o reexame da prova. Tal postura mudou na última década, com descrições mais autorais e ampliando as bases de sua argumentação. Mais próximos do objeto, os magistrados demonstram conhecer melhor a realidade que estáo tratando. Ainda quanto ao padráo da coerência - a intertextualidade na construçáo da decisão - que ampara a decisão, uma espécie de "senso comum" se destaca.

"Não foi previsto, mas era previsível." Esse tipo de construçáo amparada no "bom senso" nos chamou a atençáo, bem como suas transformaçōes. $\mathrm{O}$ senso comum é a forma mais recorrente de construção intertextual de argumento decisório, fazendo uso de elementos aqui analisados, como atores sociais e políticos, adjetivação, relações subjetivas, ethos e polidez. Se nas duas primeiras décadas o esforço foi de construção de um senso comum fático sobre o que é a favela - as práticas sociais, econômicas e culturais -, hoje isso não é mais significativo, nem a descrição de princípios constitucionais de direito, legislaçôes e da própria Constituição, como se fosse óbvio, por exemplo, que o Estado seja responsável objetivamente por suas açōes e omissóes. As narrativas foram ficando cada vez mais impessoais e objetivas com o passar do tempo. O tom rude e crítico deu lugar a uma visão mais cordial; questóes antes amparadas nas descriçôes de juízes de primeira instância ganharam autonomia descritiva na Corte.

\section{Consideraçóes finais}

Entre 1990 e 2009, 51\% dos julgados no TJRJ usaram a subsunção de fatos narrados a fundamentos expressos de direito ${ }^{23}$ - por exemplo, lei, princípios de direito ${ }^{24}$ e perícia. A decisão do juiz fundamenta-se em sua própria consciência. ${ }^{25} \mathrm{Se}$, por um lado, a intertextualidade e a coerência de decisōes são negativamente afetadas por essa liberdade - garantida por lei -, por outro, parece abrir espaço para uma contínua consolidaçâo de novas mentalidades na leitura da lei à luz dos contextos políticos e sociais dinâmicos da cidade. Além disso, embora esse atributo possa conduzir a um Judiciário com um ego "dissociado" do Estado, ele permite uma atuação política em relação à administração pública. Em 46\% dos casos, o tribunal decidiu com base no "bom senso" sobre o "senso comum". Este "bom senso" parece vir continuamente amadurecendo, quanto mais exposto é o magistrado às demandas individuais originadas em mundos urbanos distantes daqueles que frequenta.

Em suma, nosso corpus traz julgados que, além de aspectos formais sobre a forma de decidir - por exemplo, falta de padronização, métrica, rigor intertextual da construção da decisão -, sugerem uma transformaçáo na forma como o Judiciário entende o encaminhamento das problemáticas oriundas da realidade social das favelas. Uma transformação gradativa, que se dá à medida que a favela bate à porta do tribunal. Como sugere o discurso dos magistrados na década de 1980, a favela, que já contava com um século de história, fugia à competência do poder Judiciário, que naquela época evita se posicionar diante de quaisquer problemas originados nesse contexto. Na década de 1990, apesar das estratégias de polidez discursiva, o tribunal começa a expressar de modo explícito esta visão, ou melhor, passa a tomar decisões que responsabilizam categoricamente o poder Executivo pela ausência de ação ou negligên$\mathrm{cia}^{26}$ : "a autoridade pública sonega meios policiais para cumprir decisões de reintegração de posse" ou "omissão criminosa e abusiva". Aqui começa a criação de um ethos diferenciado, que dissocia o Judiciário do Estado, entendido como sinônimo de poder Executivo. O tribunal assume o papel de "justiceiro social", mas se exime de qualquer intervenção. Assistimos então à consolidação desta postura: a favela como um problema a ser tratado pelo Executivo a partir de uma orientação protetora do ser humano os moradores - e integrativa da infraestrutura em relação à cidade formal.

Em suma, se nos anos de 1980, o TJRJ parece pensar a favela como um problema de propriedade e, por isso, como uma realidade que foge à sua competência - aliás, um "não problema" que compete ao Executivo municipal e estadual -, sua 
forma de persuasão é a crítica e a condenação ao pagamento de indenizaçóes. A partir da década de 1990, observamos uma guinada nesta perspectiva. Ao se pensar a favela como um problema da cidade, ou seja, um problema de política pública e de demanda coletiva, surgem novas decisóes que irão corroborar a transformação daquele olhar, o que é reforçado pela aproximação entre os magistrados e o morador da favela. No entanto, fica evidente neste estudo a fragilidade dessas decisóes, muitas vezes amparadas em argumentos vazios ou em construções discursivas subjetivas, em que os desembargadores, ao final, se valem de seu "bom senso" para julgar. Mas não se pode negar, especialmente nesta última década, um processo de amadurecimento da coerência intertextual e argumentativa. Nesse sentido, o presente trabalho pretendeu dar mais um passo para suprir a lacuna de análises que aplicam conceitos, conhecimentos e ferramentas cunhados pela linguística para discutir problemas com os quais a prática do direito se depara cotidianamente. Como toda grande empreitada, os objetivos iniciais foram modestos, mas podem significar uma alavanca para iniciativas semelhantes.

\section{Notas}

1 "Favela" foi utilizada em detrimento da palavra "comunidade", pois esta última trazia julgados relativos às mais diversas comunidades, sendo poucos relacionados com as comunidades faveladas.

2 Apesar de haver um número grande de julgados no âmbito da justiça penal com a palavra "favela", na maioria desses casos o morador de favela figura na qualidade de réu (Lopes, 1989; Santos, 1989).

3 O sistema judicial adquiriu forte proeminência em muitos países latino-americanos recebendo, desde então, muitos investimentos financeiros. Os anos de 1980 geram para muitos estudiosos uma expectativa positiva no que tange à distribuição de direitos e à democratização do país (Junqueira, 1997).

4 Em um primeiro filtro foram encontradas 171 decisões; no entanto, após a leitura do conteúdo de todas, apenas 150 efetivamente discutiam a favela ou eram propostas por moradores dessas regiōes (Moreira, 2011).

5 O corpus é a amostra do discurso e os dados suplementares a serem utilizados na análise (Fairclough, 2001).
6 Nesta categoria quatro possibilidades de inter-relaçáo entre o Judiciário e outros entes se apresentaram: (1) apenas citação; (2) defesa; (3) acusação/crítica; (4) correção/corroboração de conduta.

7 Sobre o ethos, o que se observa são aspectos da construção do "eu", ou seja, como o "Judiciário" percebe a si mesmo e o seu papel. Sobre a perspectiva da polidez, verificamos a maneira pela qual tal ethos se relaciona socialmente com os participantes da construção discursiva.

8 Trata-se de um ensaio para posterior aprofundamento no teor das decisóes.

9 Os primeiros recenseamentos nos anos de 1940 e 1950 traziam dados conflitantes e imprecisos, o que foi sendo corrigido nas décadas seguintes, com base em novas pesquisas que até hoje são realizadas a fim de diagnosticar a evolução das favelas cariocas.

10 Termo para descrever projéteis de arma de fogo que perdendo o alvo original alcançam qualquer lugar ou pessoa no trajeto.

11 As análises da prática social na favela realizada por desembargadores do TJRJ poderão ser conferidas em passagens ao longo deste estudo.

12 Entre 2000 e 2009, esse cenário se transformou, invertendo drasticamente o perfil ora configurado: a grande maioria dos demandantes passa a ser de moradores de favelas (Moreira e Cittadino, 2013).

13 Trata-se de julgamento proferido em 11 de novembro de 1993 pela desembargadora Bias Gonçalves da Segunda Câmara Civil do TJRJ em sede de apelação. Processo n. 0007926-77.1993.8.19.0000 (1993.001.04156) com a seguinte ementa: "divórcio direto - partilha de bens - posse - Partilha de bens em ação direta de divórcio. Suficientemente comprovada a existência de posse mais que trintenária sobre terreno e benfeitorias em favela, com valor econômico, deve constar da sentença de divórcio a parcela desse direito que cabe a cada ex-cônjuge. Parcial provimento do recurso do autor, para inclusão da partilha na sentença de divórcio, restando prejudicada a preliminar de nulidade do processo, porque decidido o mérito em favor daquele a quem aproveitaria a sua decretação (DP) (grifo nosso).

14 Mais de uma década depois, em 2008, a desembargadora Maria Henriqueta Lobo adere à interpretação de que imóvel em favela não possui valor comercial. Trata-se do julgado proferido em 4 de junho de 2008 pela Sétima Câmara Civil do TJRJ em sede de Agravo de Instrumento. Processo n. 0015054-26.2008.8.19.0000 (2008.002.06554), com a seguinte ementa: "Agravo de instrumento. Execução de título judicial. Penhora de 
bem imóvel. Pedido de substituição do bem penhorado. Indeferimento. Não anuência do credor. Bem imóvel oferecido pelo executado em substituição que se encontra encravado dentro de uma favela, não possuindo qualquer valor no mercado imobiliário. É lícito ao credor recusar bens oferecidos à penhora que se revelarem de difícil alienação, isto porque a execução é feita no seu interesse, e não no do devedor. Inexistência, ainda, de prova nos autos do registro imobiliário competente do imóvel oferecido pelo executado. Desprovimento do recurso" (grifo nosso).

15 Vale registrar que fora de nossa amostra, nos últimos dez anos, o morador de favela, além de buscar o Judiciário para proteger sua vida e integridade física, aparece também como consumidor, quase sempre insatisfeito com a má prestaçáo de serviços de telefonia, TV a cabo, luz, gás, entre outros. As empresas aparecem em percentual significativo de demandas (Moreira e Cittadino, 2013).

16 Da primeira a vigésima Câmara Civil. Atualmente, existem 27 Câmaras Cíveis em funcionamento no TJRJ, segundo as informaçóes de seu website. Disponível em http://www4.tjrj.jus.br/camarasweb/listaDesembargadores.aspx, consultado em 6 mar. 2017.

17 As ementas são correspondentes a julgados de relatoria de 71 desembargadores do TJRJ no período de 1980 e 2009. São eles: Ellis Hermydio Figueira, Ademir Pimentel, Andre Andrade, Antonio Bastos, Antônio Carlos Amado, Azevedo Pinto, Bernardo Neto, Bias Gonçalves, Camilo Ruliere, Carlos Ferrari, Carlos Lemos, Carpena Amorim, Célio Ribeiro, Conceiçấo Mousnier, Cristina Gaulia, Ellis Hermydio Figueira, Ellis Hermydio Figueira, Ernani Klausner, Ferdinaldo do Nascimento, Fernando Lemos, Gabriel Zefiro, Gilberto Moreira, Gustavo Horta, Helda Meireles, Helena Gaede, Horacio Neto, Humberto Perri, Ismenio de Castro, Itamar Barbalho, Jair Pontes de Almeida, Jayro S. Ferreira, Jorge Magalhães, José Filho, José Varanda, Leila Albuquerque, Leila Mariano, Luis Felipe Salomão, Luisa Souza, Luiz Fernando de Carvalho, Luiz Odilon Bandeira, Marco Aurélio de Melo, Marco Aurélio Froes, Marco Ibrahim, Marcos Torres, Marcus Alves, Maria Henriqueta Lobo, Maria Stella Rodrigues, Mario Manheimer, Mário Neto, Miguel Barros, Monica de Oliveira, Murillo Fabregas, Murilo de Carvalho, Nametala Jorge, Nanci Mahfuz, Nilson de Castro Diao, Orlando Secco, Paulo Sergio Fabião, Pedro Raguenet, Perlingeiro Lovisi, Renato Simoni, Ronald Valladares, Ronaldo Passos, Semy Glanz, Sergio Cavalieri Filho, Sérgio Cruz, Siro Darlan, Sylvio
Capanema, Valeria Maron, Vera Hombeeck, Wilson Marques. Atualmente, existem 177 desembargadores atuando no TJRJ, segundo as informaçôes de seu website. Disponível em http://www4.tjrj.jus.br/ camarasweb/listaDesembargadores.aspx, consultado em 6 mar. 2017.

18 Também foram incluídos na soma as modalidades de termo Carta Federal, Carta Magna e Constituição da República Federativa do Brasil (CRFB).

19 Alguns exemplos de como se estabelece discursivamente esse tipo de relaçáo: "situação da favela e do processo de favelização"; "condição do favelado"; "dinâmicas locais do menor da favela e/ou da vida na favela".

20 Alguns exemplos de como se estabelece discursivamente esse tipo de relação: "o fato de o Executivo não cumprir decisões"; "desdenha de valor indenizatório de prestadora de serviços"; "Executivo em morosidade criminosa e/ou tolerante com ilegalidades"; "poder de polícia criminoso"; "condutas abusivas em geral ou omissivas em geral”.

21 Alguns exemplos de como se estabelece discursivamente esse tipo de relação: Estado "não pode ser responsável por todas as mazelas" (decisão isolada); "conduta culturalmente esperada para moradores de favelas em casos de acidentes por trânsito em locais de risco".

22 Alguns exemplos de como se estabelece discursivamente esse tipo de relação: "votos de colegas desembargadores"; "a decisão de juízes de primeira instância"; "descrição feita pelo patrono da causa na inicial"; "a avaliaçáo e laudo do perito".

23 Até final da década de 1990, a subsunção de fatos à lei significava descrever fatos, ilustrar e justificar costumes, descrever legislaçóes e justificar perspectivas de aplicação do direito àquela realidade. No início da década de 2000, a descriçâo da realidade é a primeira a ser deixada de lado: o costume social, econômico e cultural da favela deixou de ser uma realidade exótica, tornando-se um fato rotineiro, "notório", "sabido por todos”, assim como a atuação do poder Executivo. Mais recentemente, a partir da segunda metade da última década analisada, é a legislação que carece de menção expressa e detalhamento.

24 Exemplo de subsunção a princípios de direito: "dentro do princípio da legalidade, que é obrigado a observar, tomado as providências, que lhe competiam, que não impediu os danos, não comprovados, afinal, nos autos, obrigando à improcedência da ação [...]" (Des. Maria Stella Rodrigues no julgamento da apelação 0007297-64.1997.8.19.0000 [1997.001.03728] em 18/11/1997 na Segunda Câmara Cível). Exemplo 
de subsunção à prova pericial e à prova documental: "sentença monocrática fundada em provas documental, pericial, e oral, reconheceu a inexistência de culpa [...]” (Des. Maria Stella Rodrigues no Julgamento da apelação 0007297-64.1997.8.19.0000 [1997.001.03728] em 18/11/1997 na Segunda Câmara Cível). Exemplo de subsunção às súmulas: "os juros moratórios, numa e noutra, correm a contar do trânsito em julgado (Sumulas do STJ - Verbetes ns. 69 e 70)" (Des. Ellis Hermydio Figueira no julgamento da apelação 0002106-09.1995.8.19.0000 [1995.001.04102] em 09/04/1996 na Primeira Câmara Cível).

25 Isto constitui sua autonomia funcional, independência, por vezes expressamente escrita pelo magistrado, de forma rude para com patronos de partes, a fim de deixar claro que está fazendo uso dessa garantia constitucional.

26 O grande destaque, então, é a virada na década de 1990, quando o TJRJ começa a assumira favela como um problema de sua competência. Quando as demandas se tornam um problema a ser enfrentado, por meio de diferentes estratégias - fundamentação legal, citação de atores sociais, adjetivação, bom senso - há um deslocamento do campo do direito para o campo da política pública. Pudemos observar isso em reiterados pedidos indenizatórios: o TJRJ, além de determinar o pagamento de indenizaçóes, em 1995, chega a proferir uma sentença que determina a remoção de uma favela. Um período em que percepçóes como "é absurda a troca de tiros entre agentes do poder público e indivíduos desconhecidos, ditos traficantes, que não a provocaram" (Decisão em recurso de apelação no acórdão 000560076.1995.8.19.000 proferido pela quarta câmara cível em julgamento em 18/06/1996) se contrapóem a percepçôes de que "os fatos ocorridos neste cenário exigem prudência e aprofundada análise do julgador, de modo a não se deixar embalar pelas falsas aparências e se creditar ao Estado todas as consequências dos malefícios ocorridos, como se fosse para-raios por todas as desditas" (Decisão em recurso de apelação no acórdão 0005600-76.1995.8.19.000 proferido pela quarta câmara cível em julgamento em 18/06/1996). Além do debate político e da construçáo de valores sociais, chama atenção nesta década o tipo de valor moral a partir do qual decisões começam a ser proferidas. Destacamos aqui, uma manifestação emblemática verificada no período. Trata-se do discurso para decisão sobre cabimento ou não de indenização por danos morais a uma mulher, moradora da favela, que aparece em foto ilustrativa de reportagem sobre "mulheres seduzindo policiais em favelas". Neste caso, o Tribunal entendeu que "já que se trata de acadêmica de direito e que há anos vive com companheiro" (Acórdão em recurso de apelaçáo. Processo n. 0007149-58.1994.8.19.0000. Proferido pela primeira câmara cível em 21/02/1995) é cabível a indenização. Dessa forma, reduz a moralidade a um estereótipo, como se uma jovem moradora de favela, caso não esteja comprometida e matriculada em curso de direito, fosse suscetível a este tipo de comportamento. O esforço do favelado para provar seu valor moral parece maior que o do náo favelado.

\section{BIBLIOGRAFIA}

BAUMAN, Zygmunt. (2009). "Entrevista especial com ZigmuntBauman: ecologia humana". Disponível emhttp://www.portaldomeioambiente.org.br/ecologia-humana/2142-entrevista-especial-zygmunt-bauman-primeira-parte. html, consultado em 17 out. 2010.

CARVALHO, José Murilo de (2002). Cidadania no Brasil: o longo caminho. 3 ed. Rio de Janeiro, Civilização Brasileira.

CAVALCANTI, Mariana. (2009). "Do barraco a casa: tempo, espaço e valor(es) em uma favela consolidada”. Revista Brasileira de Ciências Sociais, 24 (69): 69-80.

CEZAR, Paulo Bastos. (2002), "Evolução da população de favelas na cidade do Rio de Janeiro: uma reflexáo sobre os dados mais recentes". Revista Coleção Estudos Cariocas, 2: 1-13.

FARIA, José Eduardo. (1989a), "Apresentação", in J. E. Faria (org.), Direito e Justiça, a função social do Judiciário, São Paulo, Ática.

FARIA, José Eduardo. (1989b), "O modelo liberal de direito e Estado: direito e justiça, a função do Judiciário", in J. E. Faria (org.), Direito e Justiça, a função social do Judiciário, São Paulo, Ática.

FARIA, José Eduardo. (1989c), “Ordem legal x mudança social: a crise do Judiciário e a formação do magistrado", in J. E. Faria (org.), Direito e Justiça, a função social do judiciário, São Paulo, Ática.

FARIA, José Eduardo. (2003), "Direito e justiça no século XXI: a crise da justiça no Brasil”. Anais do Congresso International Conference on Law in the 21st Century, 29: 31-39. 
FARIA, José Eduardo \& LOPES, José Reinaldo de Lima. (1989), "Pela democratização do Judiciário”, in J. E. Faria (org.), Direito e Justiça, a função social do judiciário, São Paulo, Ática.

FOUCAULT, Michel. (1998), A ordem do discurso. São Paulo, Loyola.

FAIRCLOUGH, Norman. (2001), Discurso e mudança social. Brasília, Editora da UnB.

FISCHER, Rosa Maria Bueno. (2001), "Foucault e a análise do discurso em educação". Cadernos de Pesquisa, 114: 197-223.

HOLSTON, James. (2013), Cidadania insurgente: disjunçóes da democracia e da modernidade no Brasil. São Paulo, Companhia das Letras.

JUNQUEIRA, Eliane Botelho. (1996), “Acesso à Justiça: um olhar retrospectivo". Revista Estudos Históricos, 18: 389-402.

JUNQUEIRA, Eliane Botelho; VIEIRA, José Ribas \& FONSECA, Maria Guadalupe Piragibeda. (1997), Juizes: retrato em preto e branco. Rio de Janeiro, Letra Capital.

MOREIRA, Rafaela Selem. (2006), Efetivação de direitos: limites e possibilidades no contexto de uma favela carioca. Monografia de conclusão de curso, Rio de Janeira, Pontifícia Universidade Católica.

MOREIRA, Rafaela Selem. (2007), "Mediação de conflitos: limites e possibilidades no contexto de uma favela carioca". Revista Direito, Estado e Sociedade, 30: 212-229.

MOREIRA, Rafaela Selem. (2011), Democratizaçáo do Judiciário na cidade do Rio de Janeiro: um estudo sobre o acesso individual e coletivo de moradores de favelas à justiça contextualizado à luz de uma história de desigualdades. Dissertação de mestrado, Rio de Janeiro, Pontifícia Universidade Católica.

MOREIRA, Rafaela Selem \& CITTADINO, Gisele. (2013), "Acesso individual e coletivo de moradores de favelas à justiça". Revista Brasileira de Ciências Sociais, 28 (81): 33-48.

NERI, Marcelo Côrtes. (2010), "Desigualdade e favelas cariocas: a cidade partida está se integrando?” Rio de Janeiro, FGV, CPS - Centro de Políticas Sociais Fundação Getúlio Vargas.

PADUA, João Pedro. (2009). "Ferramentas sociolínguísticas na formação de inferências conversacionais: uma aplicação a conversas telefônicas interceptadas pela polícia brasileira”. Trabalho apresentado no XV Congresso da Assel-Rio. Rio de Janeiro, UFRJ.

SANTOS, Boaventura de Souza. (1988), O discurso e o poder: ensaio sobre a sociologia da retórica jurídica. Porto Alegre, S. A. Fabris.

SANTOS, Boaventura de Souza. (1989), "Introdução à sociologia da administração da justiça”, in J. E. Faria (org.), Direito e Justiça, a função social do judiciário, São Paulo, Ática.

SANTOS, Boaventura de Souza. (2007), Renovar a teoria crítica e reinventar a emancipação social. São Paulo, Boitempo.

SANTOS, Boaventura de Souza. (2008), Para uma revolução democrática da justiça. 2. ed. São Paulo, Cortez.

SABREN. (2010), Sistema de Assentamentos de Baixa Renda (Sabren). Banco de dados da prefeitura da cidade do Rio de Janeiro. Disponível em http://portalgeo.rio.rj.gov.br/sabren/index. HTM, consultado em 10 jul. 2009.

VALLADARES, Lícia do Prado. (2005), A invenção da favela: do mito de origem a favela.com. Rio de Janeiro, FGV.

VENTURA, Zuenir. (1995), Cidade partida. Rio de Janeiro, Companhia das Letras. 


\section{DISCURSOS JUDICIAIS SOBRE FAVELAS: IMPACTO EM POLÍTICAS PÚBLICAS E NOS AGENTES SOCIAIS}

\section{Rafaela Selem Moreira e Roberto Fragale}

Palavras-chave: Análise; Discurso; TJRJ; Jurisprudência; Favela.

Este texto propóe um estudo acerca do conteúdo e da forma do discurso em decisôes judiciais do TJRJ sobre favelas entre 1980 a 2009. Fizemos uso de abordagem analítica quantitativa abrangente e abordagem analítica quanti-qualitativa específica para análise de discurso. A amostra revelou um número superior de processos propostos por moradores de favelas que discutem a prestação de serviços públicos e privados. Quanto ao discurso judicial, verificamos que o Judiciário se diferencia do Estado. Há ainda outros aspectos críticos como a falta de padronização, a métrica e o rigor intertextual na construção do discurso decisório. Os dados analisados sugerem que o Judiciário fluminense apresenta três diferentes fases no tratamento da favela: (1) de não-problema a (2) problema assumido e, por fim, (3) realidade social a ser acolhida e integrada. Ao final, constata-se, porém, que o Judiciário, nesse período, faz da favela um problema dos "Outros".

\section{JUDICIAL DISCOURSES ON FAVELAS: IMPACT ON PUBLIC POLITICS AND SOCIAL AGENTS}

\author{
Rafaela Selem Moreira and \\ Roberto Fragale
}

Keywords: Analysis; Discourse; TJRJ; Jurisprudence; Favela.

This paper analyses Brazilian judicial discourse from the State Court of Rio de Janeiro (TJRJ) in cases related to favelas (slums) of the city for three decades: from 1980 to 2009. The corpus of analyses (sample) is composed by the resumée (ementa) of TJRJ decisions. The content was analyzed through a quantitative analytical approach using the categories: author, defendant, type of action; and through a specific quanti-qualitative analytical approach of discourse based on Fairclough methodology for discourse analysis. The sample revealed a higher number of cases proposed by favela residents who discuss the provision of public and private services. As for the judicial discourse, we find that the Judiciary differs from the State. There are also other critical aspects as: lack of standardization; lack of metrics; lack of intertextual rigor and coherence among judicial decisions. Based on this study we suggest three different phases in the treatment dispensed by TJRJ to favelas: first, they are a nonproblem (denial); secondly, a recognized public problem; third, a social reality that needs to be welcomed and integrated to the city. However, that integration seems to be a problem of others (i.e., the executive and legislative's), not belonging to the justice system.

\section{DISCOURS JUDICIAIRES SUR LES FAVELAS : IMPACT SUR LES POLITIQUES PUBLIQUES ET LES ACTEURS SOCIAUX}

\author{
RafaelaSelem Moreira et Roberto \\ Fragale
}

Mots-clés: Analyse; Discours; TJRJ; Jurisprudence; Favela.

Ce texte propose une étude à propos du contenu et la forme du discours dans les décisions judiciaires du Tribunal de Justice de Rio de Janeiro (TJRJ) par rapport aux favelas entre 1980 et 2009. Nous avons, pour l'analyse du discours, fait usage d'une approche analytique quantitative et qualitative spécifique. L'échantillon a révélé un nombre plus élevé de procédés proposés par les habitants des bidonvilles qui discutent à propos de la prestation des services publics et privés. Il existe, en outre, d'autres aspects critiques, comme le manque de normalisation, la métrique et la rigueur intertextuelle dans la construction du discours décisionnel. Les données analysées suggèrent que le pouvoir Judiciaire de Rio de Janeiro présente trois étapes différentes dans le traitement de la favela : (1) d'un non-problème à (2) un problème réel et, finalement, (3) d'une réalité sociale à être accueillie et intégrée. Nous constatons, en conclusion, que le pouvoir Judiciaire, tout au long de cette période, transforme les favelas en un problème des "Autres ". 